\title{
Effect of Potassium Fertilizer and Lime Application on Yield and Quality of Soybean (Glycine max L. (merrill) in Acidic Soil of Gobu Sayo District, Western Oromia, Ethiopia
}

\author{
Negash Teshome* Woyessa Garadew \\ $\mathrm{PhD}$, Jimma University Lecturer \\ Endalkachew W/Meskel \\ PhD, ILRI, Addis Ababa
}

\begin{abstract}
The experiment was to evaluate the influence of potassium fertilizer and liming the soil on yield, yield related traits and quality of soybean (Glycine max L. (merrill) on acidic soil in Gobu Sayo district, western Ethiopia. Soil acidity problem is one of the bottlenecks to improve crop production in high rainfall areas of Ethiopia in general and in western parts of the country in particular. A field experiment was carried out during the 2016 main cropping season at three locations (Gishe, Laften and Ago). Five levels of potassium fertilizer $\left(0,20,40,60\right.$, and $80 \mathrm{~kg}^{-}$ $\left.{ }^{1}\right)$ and two levels of lime ( 0 and $\left.4.6 \mathrm{tha}^{-1}\right)$ were applied as two factors. Fifty (50) $\mathrm{kg} \mathrm{ha}^{-1} \mathrm{P}_{2} \mathrm{O}_{5}$ with seed inoculation by biological organism (legume fix strain) was also used as standard check. The eleven treatment combinations were arranged in a randomized complete block design (RCBD) with three replications. KCL was used as $\mathrm{K}_{2} \mathrm{O}$ source and applied in two splits at planting time and at vegetative growth stage. The full dose of lime was broadcasted a month before planting on those plots which received lime. The analysis of variance indicated that there were highly significant interactions $(\mathrm{P}<0.001)$ between potassium and lime applications for most measured plant variables, especially on yield and quality parameters except number of seeds per pod. The highest soybean grain yield (3642 $\mathrm{kg} \mathrm{ha}^{-1}$ ) was obtained at Gishe site when $60 \mathrm{kgha}^{-1} \mathrm{~K}_{2} \mathrm{O}$ and 4.6 ton ha-1 lime was applied while the lowest yield $\left(1014 \mathrm{kgha}^{-1}\right)$ was recorded at Ago site for the control treatment. As quality of seed, application of $\mathrm{K}_{2} \mathrm{O}$ significantly increased protein content of soybean seeds but lime interaction with $\mathrm{K}_{2} \mathrm{O}$ and $\mathrm{K}_{2} \mathrm{O}$ alone had negative effect in reducing oil content of soybean seeds. Hence, $\mathrm{K}_{2} \mathrm{O}$ at a rate of $60 \mathrm{kgha}^{-1}$ with 4.6 tha ${ }^{-1}$ lime were recommended to increase grain yield of soybean in acidic soils of the study areas. However, the response of soybean having different maturity groups and inoculation of different biological strains should further be tested in combination with liming and potassium fertilizer to come up with conclusive recommendations.
\end{abstract}

Keywords: Acidic Soil; Lime; Potassium; Quality; Soybean; Yield

DOI: $10.7176 / \mathrm{FSQM} / 90-01$

Publication date:September $30^{\text {th }} 2019$

\section{INTRODUCTION}

Soybean (Glycine max (L.) Merrill) is a small erect and branching annual leguminous plant classified under the family Fabacae and sub family Paplionodeae (Sinclair et al., 2001). In Ethiopia, grain legumes occupy about $13 \%$ of the cultivated land and their contribution to agricultural value addition is around $10 \%$ (CSA, 2012). Pulses are the third-largest export crops of Ethiopia after coffee and sesame, contributing USD 90 million to export earnings in 2007/08 (IFPRI, 2010). Among food legumes grown in Ethiopia, soybean is gaining more importance in recent years. Extensive works have been done to incorporate soybean as a food legume in people's diets, either directly in seed form or processed into value-added foods (soy nuts, soy milk, and soy pulp) or added as a blend in traditional foods. Recently, the trend of increment in area under the crop is mainly due to a rising demand from domestic processing industries. Large-scale production of the crop may, therefore, enhance the income of smallscale farmers. The country can also earn a substantial amount of foreign currency from the export of soybean grain owing to the strategic location of the country to the world consumers.

In Ethiopia, its productivity is far below the from world average, as the national average yield of the crop is less than 2 tons per hectare (CSA, 2015). This is mainly due to lack of appropriate production packages, low productivity of varieties, soil acidity problem, and lack of promotional activities suitable for different cropping systems and agro-ecologies (Urgessa, 2015). Soil acidity and decline in soil fertility are forms of soil degradation adversely affecting sustainable crop production in Ethiopia in general, and in western Ethiopia in particular (Abdenna, et al., 2007). Achieving optimum soil pH is essential for field crop production, because it affects many soil properties and processes, including nutrient cycling, soil microbial activity, and soil structure. Soil acidity affects root development, leading to reduced nutrient and water uptake and deficiency in essential plant nutrients, such as K, Ca, and Mg (Abdenna, et al., 2007).

Recent studies showed that depletion of major nutrients is very high in Ethiopia particularly in western parts of the country (Abdenna, et al., 2007). Low soil P availability due to its high fixation in acidic soils is limiting 
crop production. A study also showed that soil acidity increased on cultivated lands in western part of Ethiopia because of the intensity of the high rainfall (Achalu et al., 2012). Moreover, different reports indicated that most cultivated lands of the Ethiopian highlands in general and western parts in particular are prone to soil acidity due to removal of ample amount of nutrients by leaching, crop mining and runoff as compared with grazing and forest lands (IFPRI. 2010). It is now becoming a serious challenge to crop production in these parts of the country and an inventory was made in 2006 to determine the current status of soil acidity of Nitisols occurring in western and central Ethiopia. The results revealed that all samples were acidic though the degree varied from location to location (Abdenna, et al., 2007). These authors indicated that soil acidity problem that occurred particularly in western zones of Oromia was very critical and deserved immediate intervention to amend the soils for crop production. Besides, potassium is one of the three major essential nutrient elements required by plants. Unlike nitrogen and phosphorus, potassium does not form bonds with carbon or oxygen, so it never becomes a part of protein and other organic compounds (Hoeft et al., 2000). Although $\mathrm{K}$ is not a constituent of any plant structures or compounds, it is involved in nearly all processes needed to sustain the plant life. Potassium in cell sap is involved in enzyme activation, photosynthesis, transport of sugars, protein and starch synthesis. It is known to help crop to perform better under water stress through the regulation of the rate at which plant stomata open and close. It is also known for its role to provide lodging resistance and insect/disease resistance to plants. Since potassium is involved in many metabolic pathways that affect crop quality, it is often called as "the quality element". Plants absorb $\mathrm{K}$ in larger amounts than any nutrient except $\mathrm{N}$. Potassium $(\mathrm{K})$ as essential mineral nutrient and is required in relatively large amount to maintain growth and play a central role in improving crop yield and quality (Abel et $a l ., 2002)$. In our country in general and in western Ethiopia in particular, no information is available on the role of potassium fertilizer on yield and quality aspects of soybean.

Accordingly, Bako Agricultural Research Center in collaboration with N2-Africa project has conducted different research activities on legume crops production in Gobu Sayo District of East Wellega Zone for the last three years. The result indicated that application of phosphorus $\left(\mathrm{P}_{2} \mathrm{O}_{5}\right)$ and inoculations/biological nitrogen fixers) significantly improved yield and yield related traits of soybean by $19 \%$. However, yield response of the crop to the inputs was inconsistent over years and across the selected Kebele of the district (N2-Africa progress report, 2013), as more than $25 \%$ of the sites showed inconsistent yield to the applied inputs. It was suspected that there were substantial variations among the selected Kebels for soil $\mathrm{pH}$, available $\mathrm{P}$ and $\mathrm{K}$, which might result in such variation in yield of the crop over years. Therefore, with the view to generate information, this study was initiated to evaluate the effect of potassium fertilizer and lime application to acidic soil on yield and quality of soybean in Gobu Sayo district, western Ethiopia.

\section{MATERIALS AND METHODS}

\subsection{Description of the Study Area}

A field experiment was conducted during the 2016 main cropping season under rain-fed condition on three purposely selected farmer fields in Ago Laften Kebele of Gobu Sayo district, Western Ethiopia. Ago Laften is one of the nine Kebeles found in Gobu Sayo district in East Wollega Zone of Western Oromia. Gobu Sayo district is located about $265 \mathrm{~km}$ to the west of Addis Ababa. The district is characterized by altitudes ranging from 1200 to 1960 meters above sea level. Its total annual rainfall is as high as $2000 \mathrm{~mm}$ and has average temperature ranging from $15-20^{\circ} \mathrm{c}$. The district has mono-modal rainfall pattern with alternative wet and dry seasons with the main rain falling between April and November, while being dry throughout the rest of the months. The selected sites for the experiment were assumed to be representative of the whole sampled areas of the location, where yield inconsistencies were recorded in previous studies. The soil of the district is nitosols with low fertility range because of high rainfall and dominance of mono-cropping system by cereal crops. The sites were selected based on the results of pre-sowing soil analysis done for ten farmers' fields where yield in consistencies were observed in previous studies (N2-Africa progress report, 2013).

The district is approximately located between $9^{\circ} 0^{\prime} 30^{\prime \prime} \mathrm{N}$ to $9^{\circ} 20^{\prime} 30^{\prime} \mathrm{N}$ latitude and $36^{\circ} 53^{\prime} 30^{\prime \prime} \mathrm{E}$ to 377'00'’E.longitude 

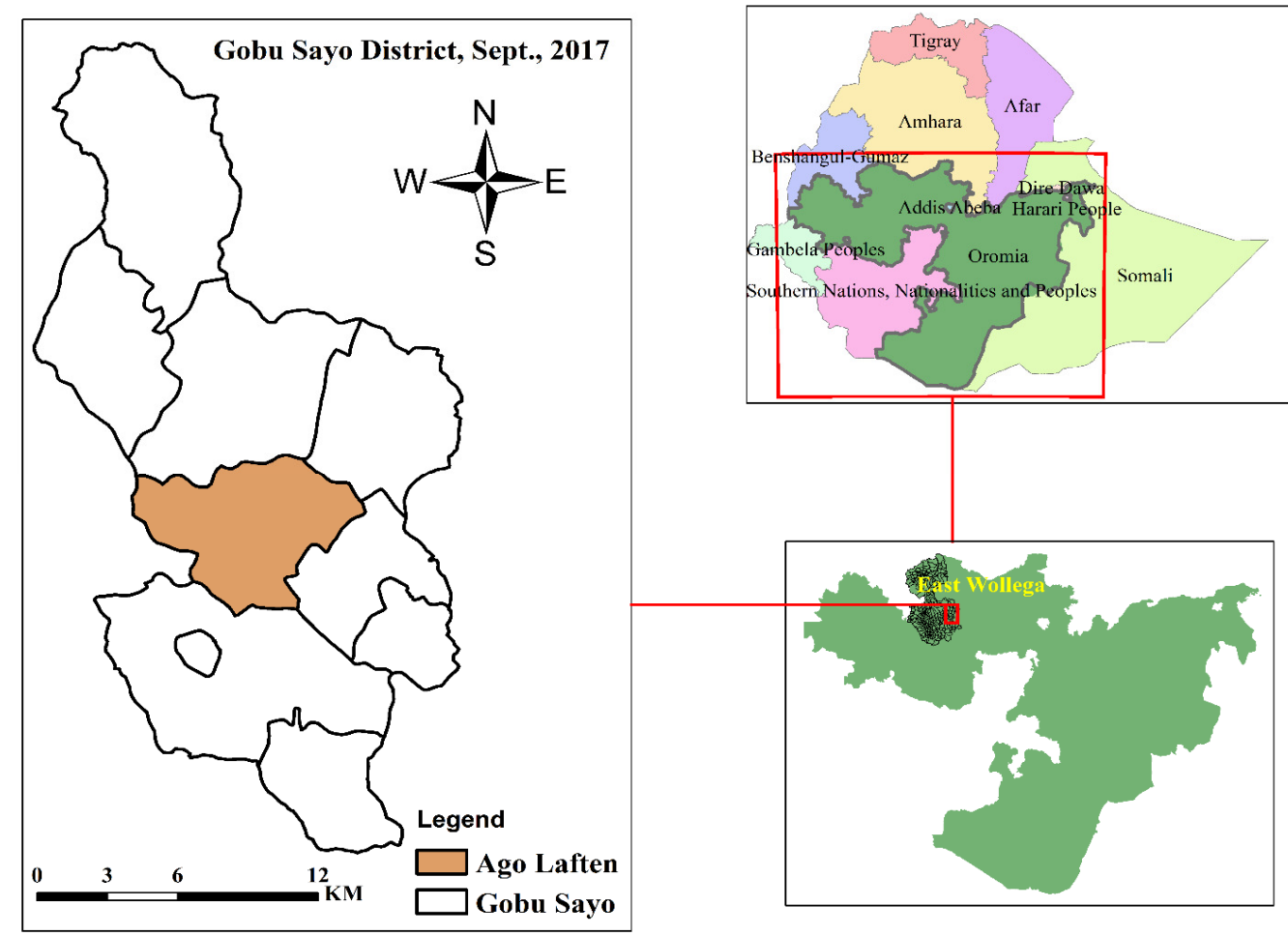

Figure 5.Location map of the study area

\subsection{Treatments and Design}

Five rates of potassium $\left(\mathrm{K}_{2} \mathrm{O}\right)\left(0,20,40,60\right.$, and $\left.80 \mathrm{kgha}^{-1}\right)$ combined with two levels of lime $\left(\mathrm{CaCO}_{3}\right)(0$ and 4.6 tha $\left.^{-1}\right)$ were used as treatments. Moreover, the recommended rate of phosphorous for the study area $\left(50 \mathrm{kgha}^{-1} \mathrm{P}_{2} \mathrm{O}_{5}\right)$ with bio-fertilizer inoculation (legume fix bio-fertilizer) was used as a standard check which is recommended by BARC before (Table 1). The bio-fertilizer was brought from Holeta Agricultural Research center. The treatment combinations were arranged in Randomized Complete Block Design (RCBD) with three replications. Soybean variety, Jalalle (AGS-217) which is an early maturity type with 90-120 days was used for the experiment. Gross experimental plot was $12.8 \mathrm{~m} \times 31.4 \mathrm{~m}$ for each locations.

Table 1. Treatments and their combinations

\begin{tabular}{lll}
\hline TRT. Code & Treatment Combinations \\
\hline Trt $_{1}$ & $0 \mathrm{tha}^{-1}$ lime $+0 \mathrm{~kg} \mathrm{ha}^{-1} \mathrm{~K}_{2} \mathrm{O} \quad$ (negative Control) \\
$\mathrm{Trt}_{2}$ & $0 \mathrm{tha}^{-1}$ lime $+20 \mathrm{~kg} \mathrm{ha}^{-1} \mathrm{~K}_{2} \mathrm{O}$ \\
$\mathrm{Trt}_{3}$ & $0 \mathrm{tha}^{-1}$ lime $+40 \mathrm{~kg} \mathrm{ha}^{-1} \mathrm{~K} 2 \mathrm{O}$ \\
$\mathrm{Trt}_{4}$ & $0 \mathrm{tha}^{-1}$ lime $+60 \mathrm{~kg} \mathrm{ha}^{-1} \mathrm{~K} 2 \mathrm{O}$ \\
$\mathrm{Trt}_{5}$ & $0 \mathrm{tha}^{-1}$ lime $+80 \mathrm{~kg} \mathrm{ha}^{-1} \mathrm{~K}_{2} \mathrm{O}$ \\
$\mathrm{Trt}_{6}$ & $4.6 \mathrm{t} \mathrm{ha}^{-1}$ lime $+0 \mathrm{~kg} \mathrm{ha}^{-1} \mathrm{~K}_{2} \mathrm{O}$ \\
$\mathrm{Trt}_{7}$ & $4.6 \mathrm{tha}^{-1}$ lime $+20 \mathrm{~kg} \mathrm{ha}^{-1} \mathrm{~K}_{2} \mathrm{O}$ \\
$\mathrm{Trt}_{8}$ & $4.6 \mathrm{tha}^{-1}$ lime $+40 \mathrm{~kg} \mathrm{ha}^{-1} \mathrm{~K} 2 \mathrm{O}$ \\
$\mathrm{Trt}_{9}$ & $4.6 \mathrm{t} \mathrm{ha}^{-1}$ lime $+60 \mathrm{~kg} \mathrm{ha}^{-1} \mathrm{~K}_{2} \mathrm{O}$ \\
$\operatorname{Trt}_{10}$ & $4.6 \mathrm{tha}^{-1}$ lime $+80 \mathrm{~kg} \mathrm{ha}^{-1} \mathrm{~K}_{2} \mathrm{O}$ \\
$\operatorname{Trt}_{11}$ & $50 \mathrm{~kg} \mathrm{ha}^{-1} \mathrm{P}_{2} \mathrm{O}_{5}+$ inoculation with legume fix strain (Standard check) \\
\hline
\end{tabular}

\subsection{Experimental Procedure}

Field layouts and fine seed bed was prepared according to the design. Lime was applied to plots which receive the treatment prior one month of planting to buffer the soil and each treatment was assigned randomly to the experimental units within a block. Planting was done at the end of June, 2016. Potassium (K) was applied in two split applications at time of planting and at rapid vegetative growth stage when plants transit from vegetative to flowering stage, because young seedlings of soybean do not use much potassium, but the rate of uptake climbs to a peak during the period of rapid vegetative growth. Manual weed control and all recommended agronomic practices for the crop were performed during the cropping season. 


\subsection{Statistical Data Analysis}

All the collected data were subjected to analysis of variance using SAS version 9.3 and Gene Stat $18^{\text {th }}$ edition. Duncan's multiple range test at 5\% level of significance was used to separate the treatment means that showed significant differences.

\section{RESULTS AND DISCUSSIONS}

\subsection{Yield and Yield Components}

\subsubsection{Number of pods per plant}

The interaction of potassium and lime showed that highly significant effect $(\mathrm{P}<0.001)$ on number of pods per plant over locations. The highest number of pods per plant (82.73) was recorded for $60 \mathrm{kgha}^{-1} \mathrm{~K}_{2} \mathrm{O}$ with 4.6 tha ${ }^{-1}$ lime applications at Gishe site while the lowest value (19.80) was recorded from the control treatments at Ago site (Table 2). This result indicated that interaction of potassium fertilizer and liming the soil has positive direct effect in increasing number of pods per plant. In line with this result, (Hirpa. et al., 2013) concluded that the effect of lime was greatest for pod number per plant with an average increase of $20.2 \%$ for the lime treated soil than for the untreated soil. Similar results were reported by Kisinyo et al. (2005) who suggested that lime application neutralizes soil acidity, reduces toxicity levels of $\mathrm{Al}, \mathrm{Fe}$ and $\mathrm{Mn}$ and improves physiological, chemical and biological properties of soils; and also improves soil productivity by providing $\mathrm{Ca}$ and $\mathrm{Mg}$ and availability of $\mathrm{P}$ which in turn improve crop performance (Ponette et al., 1996). Especially, fixed P in acidic soil could be more available to plants consequently improves overall crop performance and yield.

Table 2. Mean pod numbers per plant (NPPP) of soybean as affected by the interaction of liming and potassium levels at three locations in Gobu Sayo district (in 2016 cropping season).

\section{NPPP}

\begin{tabular}{|c|c|c|c|c|c|c|c|}
\hline & Locations & GISHE & \multicolumn{2}{|r|}{ LAFTEN } & \multicolumn{3}{|c|}{ AGO } \\
\hline $\begin{array}{l}\text { Potassium } \\
\text { levels }\end{array}$ & $\begin{array}{l}\text { liming(t ha- } \\
\text { 1) }\end{array}$ & 0 & 4.6 & 0 & 4.6 & 0 & 4.6 \\
\hline (kg ha-1) & & & & & & & \\
\hline 0 & & $37.47^{\mathrm{ijk} k \mathrm{mn}}$ & $40.30^{\text {hijk }}$ & $41.50^{\text {ghij }}$ & $33.70^{\mathrm{mn}}$ & $19.80^{\mathrm{O}}$ & $44.60^{\mathrm{efg}}$ \\
\hline 20 & & $39.67^{\mathrm{hijk} k \mathrm{~m}}$ & $49.80^{\text {cdef }}$ & $35.60^{\mathrm{jklmn}}$ & $41.27^{\text {ghij }}$ & $34.51^{\mathrm{kLmn}}$ & $31.50^{\mathrm{n}}$ \\
\hline 40 & & $46.93^{\text {defg }}$ & $53.93^{b c}$ & $41.00^{\mathrm{ghij}}$ & $40.33^{\text {hikj }}$ & $50.57^{\mathrm{cd}}$ & $37.00^{\mathrm{ijmn}}$ \\
\hline 60 & & $46.77^{\text {defg }}$ & $82.73^{\mathrm{a}}$ & $42.40^{\text {ghi }}$ & $44.27^{\mathrm{efgh}}$ & $39.80^{\text {hijkL }}$ & $37.33^{\mathrm{ijk} k \mathrm{lmn}}$ \\
\hline 80 & & $52.13^{\mathrm{bcd}}$ & $50.00^{\text {cde }}$ & $43.93^{\text {fgh }}$ & $42.70^{\text {ghi }}$ & $33.93^{\mathrm{Lmn}}$ & $56.70^{\mathrm{b}}$ \\
\hline CV (\%) & & 7.4 & & & & & \\
\hline $\operatorname{LSD}(5 \%)$ & & 5.21 & & & & & \\
\hline
\end{tabular}

Means followed by the same letters within columns and rows for a factor are not significantly different at $5 \%$ level of significance.

\subsubsection{Above ground dry biomass yield $\left(\mathrm{kg} \mathrm{ha}^{-1}\right)$}

The analysis of variance showed that the interaction of potassium levels and lime rates were highly significant effect $(\mathrm{P}<0.001)$ for the above ground dry biomass yield over locations. The highest biomass yield $\left(10,508 \mathrm{kgha}^{-}\right.$ ${ }^{1}$ ) was obtained from the interaction of $60 \mathrm{kgha}^{-1} \mathrm{~K}_{2} \mathrm{O}$ with $4.6 \mathrm{tha}^{-1}$ lime applications at Gishe site and it was statistically insignificant with 60 and $20 \mathrm{kgha}^{-1} \mathrm{~K}_{2} \mathrm{O}$ without lime at Laften and $80 \mathrm{kgha}^{-1} \mathrm{~K}_{2} \mathrm{O}$ with 4.6 tha ${ }^{-1}$ lime application at Gishe. The lowest biomass yield (3701 kgha ${ }^{-1}$ ) was obtained due to application of $40 \mathrm{kgha}^{-1} \mathrm{~K}_{2} \mathrm{O}$ without lime at Ago site (Table 3). From this result it was observed that above ground dry biomass yield has a direct positive relationship with the total grain yield of the crop. Because combination of $60 \mathrm{kgha}^{-1} \mathrm{~K}_{2} \mathrm{O}$ with 4.6 tha $^{-1}$ of lime gave the highest biomass yield, as well as grain yield ha ${ }^{-1}$ and the lowest biomass yield was associated with the lowest grain yield for the interaction of $40 \mathrm{kgha}^{-1}$ potassium and zero kgha ${ }^{-1}$ of lime. This result is most probably due to release of unavailable/fixed nutrients from strongly acidic soil with liming the soil and became available to the plants and, thus, contribute to above ground biomass growth of soybean. In line with this result, there is a notion which indicates that phosphorous deficiency generally decreases plant biomass accumulation by limiting interception of photo-synthetically active radiation (PAR) rather reducing efficiency of conversion of PAR in to dry matter. Similar investigation by Zeidan (2007) and Erman et al. (2009) also indicated that increasing phosphorus levels from 0 to $60 \mathrm{~kg} \mathrm{P}_{2} \mathrm{O}_{5} \mathrm{ha}^{-1}$ increased the general biomass of lentil and field pea plants and decreased at $90 \mathrm{~kg} \mathrm{P}_{2} \mathrm{O}_{5} \mathrm{ha}^{-1}$ for field pea. 
Table 3. Mean above ground dry biomass yield (BYPH) $\left(\mathrm{kgha}^{-1}\right)$ of soybean as influenced by location, potassium levels and lime rates at Gobu Sayo district in 2016 main cropping season.

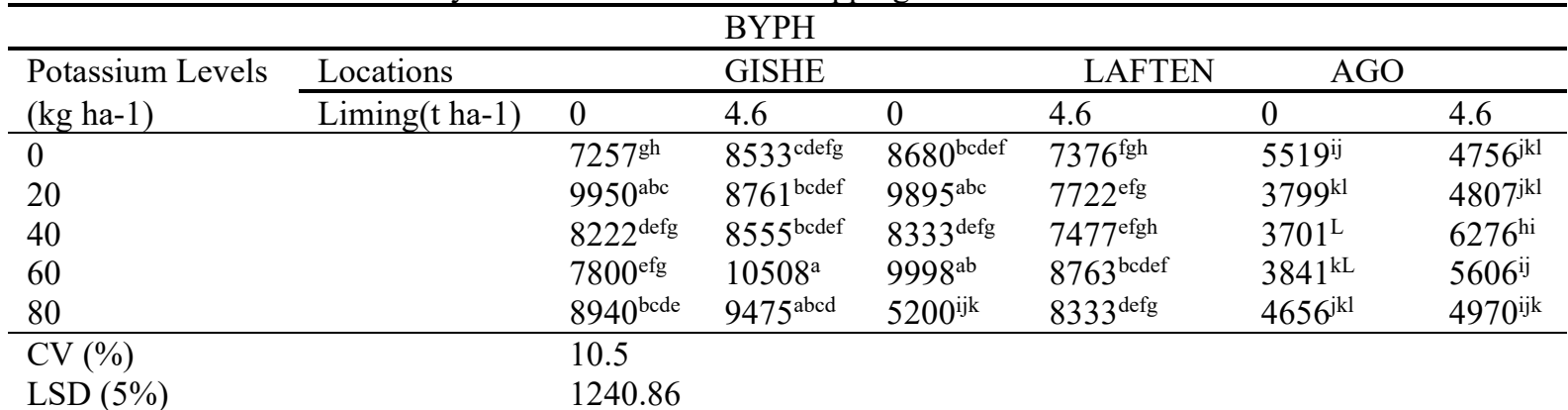

Means followed by the same letters within column and rows for a factor are not significantly different at 5\% level of significance.

\subsubsection{Number of seeds per pod}

The results of analysis of variance showed that the variations in number of seeds per pod due to the main effect of potassium or liming the soil and their interaction were non-significant. Although the main factors $\left(\mathrm{K}_{2} \mathrm{O}\right.$ or lime), and their interaction showed non-significant difference, the mean values of number of seeds per pod due to locations were significant $(\mathrm{P}<0.04)$. The highest seed number per pod (2.38) was recorded at Ago site, which was statistically non-significant at Gishe site (2.34) while the lowest value (2.23) was obtained at Laften (Table 4). Most probably number of seeds per pod may vary due to genotype differences however, seeds per pod are less affected by external factors like fertilization when a single genotype is considered. So, the variation observed over locations were due the variation/difference of environmental factors (soil factors, temperature, rain fall etc.) between the experimental locations rather than the combination of factors.

Table 4. Mean number of seed per pod (NSPP) as influenced by location in Gobu Sayo district in 2016 main cropping season.

\begin{tabular}{lcc}
\hline & Measured & Parameter \\
\hline LOCATION & NSPP \\
\hline GISHE & & $2.34^{\mathrm{a}}$ \\
LAFTEN & $2.23^{\mathrm{b}}$ \\
AGO & $2.38^{\mathrm{a}}$ \\
\hline & CV $(\%)$ & 9.8 \\
& LSD $(5 \%)$ & 0.11 \\
\hline
\end{tabular}

Means followed by the same letters within column for a factor are not significantly different at $5 \%$ level of significance.

\subsubsection{Total grain yield per hectare $\left(\mathrm{kgha}^{-1}\right)$}

The combined analysis of variance showed that mean grain yield of soybean was significantly influenced $(\mathrm{P}<0.001)$ by the interaction of potassium fertilizer and liming the soil over locations (Table 5). It was observed that $60 \mathrm{kgha}^{-}$ ${ }^{1} \mathrm{~K}_{2} \mathrm{O}$ with 4.6 tha $^{-1}$ lime gave the highest grain yield (3642 $\left.\mathrm{kgha}^{-1}\right)$ at Gishe while the lowest yield (1014 kgha-1) was obtained from the control treatment at Ago site (Table 5). In such a case, application of lime raises the soil $\mathrm{pH}$ and make essential nutrients to be in the available range to crop utilization. In line with this result, Shiferaw and Wassie et al. (2009) further substantiated by several reports that application of lime on acid soils is beneficial in situations where nutrients in the soil are made unavailable due to very low $\mathrm{pH}$ or high acidity. 
Table 5. Total grain yield (TGY) per hectare $\left(\mathrm{kgha}^{-1}\right)$ of soybean as influenced by of potassium and lime rates at three sites in Gobu Sayo district (in 2016 main cropping season).

\begin{tabular}{|c|c|c|c|c|c|c|c|}
\hline \multirow{4}{*}{$\begin{array}{l}\text { Potassium levels } \\
\text { (kg ha-1) }\end{array}$} & \multicolumn{6}{|c|}{ TYPH $\left(\mathrm{kgha}^{-1}\right)$} & \\
\hline & Location & GISHE & & LAFTEN & & AGO & \\
\hline & $\operatorname{Liming}(\mathrm{t}$ ha- 1$)$ & 0 & 4.6 & 0 & 4.6 & 0 & 4.6 \\
\hline & & & & & & & \\
\hline 0 & & $2077^{\mathrm{jk}}$ & $2776^{\text {de }}$ & $2459^{\text {fgh }}$ & $1517^{\mathrm{m}}$ & $1014^{\mathrm{n}}$ & $2398^{\text {ghi }}$ \\
\hline 20 & & $3077^{\mathrm{c}}$ & $3273^{\mathrm{bc}}$ & $2378^{\text {ghi }}$ & $1989^{\mathrm{kL}}$ & $1357^{\mathrm{m}}$ & $2038^{\mathrm{jkl}}$ \\
\hline 40 & & $2658^{\mathrm{def}}$ & $3295^{\mathrm{b}}$ & $2046^{\mathrm{jkL}}$ & $2218^{\mathrm{ij}}$ & $1459^{\mathrm{m}}$ & $1930^{\mathrm{kl}}$ \\
\hline 60 & & $2859^{\mathrm{d}}$ & $3642^{\mathrm{a}}$ & $2588^{\mathrm{efg}}$ & $3250^{\mathrm{bc}}$ & $1855^{\mathrm{L}}$ & $2209^{i j}$ \\
\hline 80 & & $2766^{\mathrm{de}}$ & $3072^{c}$ & $2345^{\mathrm{hi}}$ & $2392^{\text {ghi }}$ & $1372^{\mathrm{m}}$ & $1844^{\mathrm{L}}$ \\
\hline CV $(\%)$ & & 5.0 & & & & & \\
\hline $\operatorname{LSD}(5 \%)$ & & 192.3 & & & & & \\
\hline
\end{tabular}

Means followed by the same letters within column and rows are not significantly different at 5\% level of significance.

\section{Comparison of pooled mean yield}

Comparison of pooled mean grain yield of soybean over the three locations and lime $\left(4.6\right.$ tha $\left.^{-1}\right)$ interaction with $\mathrm{K}_{2} \mathrm{O}\left(60 \mathrm{kgha}^{-1}\right)$ over locations showed a mean grain yield of $3033.70 \mathrm{kgha}^{-1}$, but mean grain yield over the location for inoculating the seed with legume fix bio-fertilizer strain was $2254 \mathrm{kgha}^{-1}$. This result indicates that liming the soil interaction with potassium fertilizer application has more grain yield having a yield advantages $34.56 \%$ over the standard check in the study area (Table 6).

Table 6. Comparison of the pooled mean of total grain yield $\left(\mathrm{kg} \mathrm{ha}^{-1}\right)$ of the standard check and lime and potassium application over locations.

\begin{tabular}{lllll}
\hline Location & GISHE & LAFTEN & AGO & Pooled mean \\
\hline standard check & 2867 & 1969 & 1925 & 2254 \\
$\mathrm{~K}_{2} \mathrm{O}+$ Lime & 3642 & 3250 & 2209 & 3033 \\
\hline Yield Adv. (\%) & & & $34.56 \%$ \\
\hline
\end{tabular}

Note: $\mathrm{K}_{2} \mathrm{O}+$ Lime $=$ interaction of 4.6 tha $^{-1}$ lime with $60 \mathrm{Kgha}^{-1} \mathrm{~K}_{2} \mathrm{O}$, Standard check $=50 \mathrm{~kg}_{2} \mathrm{O}_{5}$ and inoculation of soybean seed with legume fix bio-fertilizer. ${ }^{* *}$ New combination of factors are interaction of 4.6 tha ${ }^{-1}$ lime with $60 \mathrm{kgha}^{-1} \mathrm{~K}_{2} \mathrm{O}$.

\subsection{Grain quality data}

\subsubsection{Grain protein content}

The results of grain protein content are presented in Table 7 and 8 . A statistically significant $(\mathrm{P}<0.006)$ variation was observed in seed protein content of soybean with different doses of potassium and lime, but their interaction was insignificant. The highest protein content was recorded from $40 \mathrm{kgha}^{-1} \mathrm{~K}_{2} \mathrm{O}$ application. On the other hand, the lowest protein content in the seed $(32.42 \mathrm{mg} / 100 \mathrm{gm})$ was recorded for the rate of $60 \mathrm{kgha}^{-1} \mathrm{~K}_{2} \mathrm{O}$. Concerning the effect of lime application, seed protein content of the control treatment (non-limed plots) was significantly higher than the limed plots. This results indicates that liming acidic soil has negative effect by reducing the protein content of soybean seed. To the contrary, since potassium is a quality element, it has the capacity to increase grain protein content of soybean. This could be due to increased availability of phosphorous, potassium and other related elements as compared to the pre-sowing composite soil conditions. Similar result has been reported for soil with high P sorption. On the other hand, Shahid et al. (2009) have reported that increasing levels of P had significant effects on protein contents of soybean.

Table: 7. Mean seed protein content of soybean as affected by potassium application in Gobu Sayo District (in 2016 main cropping season).

\begin{tabular}{lll}
\hline Treatments & Location & Protein $\mathrm{mg} / 100 \mathrm{gm}$ \\
\hline $\mathrm{K} 2 \mathrm{O}$ & GISHE & \\
\hline 0 & & 34.06 \\
20 & & 35.10 \\
40 & & 35.65 \\
60 & 32.42 \\
80 & 4.2 & 35.62 \\
\hline CV $(\%)$ & \\
LSD $(5 \%)$ & 1.78 & \\
\hline
\end{tabular}

Means followed by the same letters within column and rows are not significantly different at 5\% level of significance. 


\subsubsection{Grain oil content of soybean}

The analysis of variance showed that oil contents of soybean seed was statistically non-significantly affected by the application of $\mathrm{K}_{2} \mathrm{O}$ and its interaction with lime (Table 8). But significant effect was observed for only lime rates. The highest seed oil content $(18.76 \%)$ was recorded for non-limed and the lowest value $(18.15 \%)$ for limed treatments. This result indicates that liming the soil has negative effect on oil content of soybean seed in the study area.

Table 8. Seed protein and oil contents of soybean as influenced by liming the soil in 2016

\begin{tabular}{cccc}
\hline Lime rates $\left(\mathrm{t} \mathrm{ha}^{-1}\right)$ & Protein $(\mathrm{mg} / 100 \mathrm{gm})$ & Oil (\%) \\
\hline 0 & & 35.14 & 18.76 \\
4.6 & 34.00 & 18.15 \\
\hline & CV (\%) & 4.2 & 3.3 \\
& LSD (\%) & 1.12 & 0.47 \\
\hline
\end{tabular}

\section{SUMMARY AND CONCLUSIONS}

There was a significant increase in yield and quality parameters of soybean with application of lime and potassium. Highly significant $(\mathrm{P}<0.001)$ differences were observed among the treatments for total biomass yield, number of pods per plant, and total grain yield per hectare due to interaction of lime rates and potassium fertilizer levels. The highest soybean grain yield $\left(3642 \mathrm{kgha}^{-1}\right)$ was obtained from the interaction of $60 \mathrm{kgha}^{-1} \mathrm{~K}_{2} \mathrm{O}$ with 4.6 tha- lime applications at Gishe while the lowest yield $\left(1014 \mathrm{kgha}^{-1}\right)$ was obtained at Ago site from the control treatment. So, application of $60 \mathrm{kgha}^{-1} \mathrm{~K}_{2} \mathrm{O}$ with 4.6 tha $^{-1}$ lime has a yield advantages of $34.56 \%$ over the standard check.

In general, liming the soil plus potassium fertilizer application was useful in the study areas and similar agroecologies. Through the interaction of potassium and liming increased soybean yield, grain yield of the crop was still low as compared to the global average and its potential yield. Besides, potassium $40 \mathrm{kgha}^{-1} \mathrm{~K}_{2} \mathrm{O}$, followed by 80 and $20 \mathrm{kgha}^{-1} \mathrm{~K}_{2} \mathrm{O}$ application respectively significantly affected seed protein contents, but $\mathrm{K}_{2} \mathrm{O}$ interaction with lime has negative effect on both protein and oil contents of soybean seeds. Hence the present findings showed that lime application has negative effect in reducing both protein and oil contents on soybean seed. However, reclamation of the soil physical and chemical properties and biological activities of a soil has great importance in increasing crop production and productivity for the succeeding crops. As the present experiment was done for a season with a single crop variety, evaluation of the response of different maturity groups of soybean varieties inoculated with different Bradyrhizobium japonicum strains and their response to liming and potassium application on crop yield and seed quality parameters requires further investigation to come up with a conclusive recommendation.

\section{References}

Abdenna, D., Negassa, C.W., and Tilahun, G., 2007. Inventory of Soil Acidity Status in Crop Lands of Central and Western Ethiopia. "Utilization of diversity in land use systems: Sustainable and organic approaches to meet human needs" Tropentag, October 9-11, 2007, Witzenhausen.

Abel S, Ticconi CA, Delatorre CA (2002). Phosphate sensing in higher plants. Physiol. Plantarum, 115(1): 1-8.

Achalu, C., Heluf, G. Kibebew K, and Abi, T. 2012. Response of barley to liming of acid soils collected from different land use systems of western Oromia, Ethiopia. Journal of Bio-diversity and Environmental Sciences, 2(5): pp 37-49.

CSA (Central Statistical Agency), 2012. Report on Area on and Crop Production Forecast for major crops .Statistical Bulletin 505. Addis Ababa, Ethiopia.

CSA (Central Statistical Agency), 2015. Report on Area and Crop Production Forecast for major crops. Addis Ababa, Ethiopia.

Erman, M., B. Yildirim, N. Togay and F. Cig, 2009. Effect of phosphorus application and Rhizobium inoculation on the yield, nodulation and nutrient uptake in field pea (Pisum sativum sp .arvense L.). Journal of Animal and Veterinary Advances, 8(2):301-304.

Hirpa, L., Nigussie-D., Setegn G., Geremew B., and Firew M., 2013. Response to Soil Acidity of Common Bean Genotypes (Phaseolus vulgaris L.) Under Field Conditions at Nedjo, Western Ethiopia.

IFPRI, 2010. Fertilizer and Soil Fertility Potential in Ethiopia: Constraints and opportunities for enhancing the system.

Kisinyo, P.O., C.O. Othieno, J.R. Okalebo, M.J. Kipsat, A.K. Serem and D.O. Obiero 2005. Effects of lime and phosphorus application on early growth of Leucaenain on acid soils. Afr. Crop Sci. Conf. Proc., 7: 12331236.

Ponette, Q., S. Belkacem and C.Nys, 1996. Ion dynamics in acid forest soils as affected by addition of Ca fertilizers. Geoderma, 71:53-76. 